\title{
Selected Essential and Non-Essential Elements Content of Turkish Hazelnuts
}

\author{
Emine Elmaslar Ozbas ${ }^{1}$, H. Eser Okten ${ }^{2}$, H. Kurtulus Ozcan ${ }^{1} \&$ Goksel Demir ${ }^{2}$ \\ ${ }^{1}$ Department of Environmental Engineering, Engineering Faculty, Istanbul University, Istanbul, Turkey \\ ${ }^{2}$ Department of Environmental Engineering, Faculty of Engineering, Bahcesehir University, Istanbul, Turkey \\ Correspondence: Emine Elmaslar Ozbas, Department of Environmental Engineering, Engineering Faculty, \\ Istanbul University, Avcilar 34320, Istanbul, Turkey Tel: 90-212-473-7070 ext.17724. E-mail: \\ elmaslar@istanbul.edu.tr
}

Received: September 20, 2012 Accepted: November 1, 2012 Online Published: December 17, 2012

doi:10.5539/ep.v2n1p81

URL: http://dx.doi.org/10.5539/ep.v2n1p81

\begin{abstract}
Besides being the largest hazelnut producer in the world, Turkey was also the foremost hazelnut exporting country. In this study, content of essential metals $(\mathrm{Na}, \mathrm{Mg}, \mathrm{Ca}, \mathrm{K}, \mathrm{Fe})$ and toxic metals $(\mathrm{Cu}, \mathrm{Pb}, \mathrm{Cd})$ in hazelnut samples from eastern and western parts of Black Sea Region in Turkey were analyzed, and the relationship among these metals were investigated. In addition, the estimated daily intake (EDI) of heavy metals was calculated. It was shown that the calculated EDI values for daily average consumption $(20 \mathrm{~g})$ were lower than the recommended values for $\mathrm{Cu}$. Moreover, $\mathrm{Cd}$ and $\mathrm{Pb}$ were not detected in any of the samples. Potassium was observed to have the highest concentration with an average of $2348.37 \mathrm{mg} \cdot \mathrm{kg}^{-1}$ among the investigated elements. In addition, $\mathrm{Ca}$ and $\mathrm{Mg}$ contents in hazelnut samples were also found to be rather high.
\end{abstract}

Keywords: hazelnut, heavy metals, elemental composition, Turkey

\section{Introduction}

The main production areas of hazelnut (Corylus avellana) in Turkey were categorized in two parts: the first part was at the eastern Black Sea region, including Ordu, Giresun, Rize, Trabzon and Artvin provinces. The second part included Sakarya, Samsun, Sinop, Kastamonu, Bolu, Duzce, Zonguldak, and Kocaeli provinces, which corresponded to middle and western parts of Black Sea region. Currently there were 180 crushing facilities and 40 processing facilities with annual capacities of 1.8 million tons and 350,000 tons, respectively (FTG, 2011).

In 2010, total hazelnut export of Turkey was reported to be 252,305 tons, which provided 1.5 billion US dollars in export revenue (BSEA, 2011). Hazelnut production in Turkey was on average 500,000 tons on a yearly basis, comprising about $70 \%$ of the world's hazelnut production. About 200,000 tons were exported to European countries such as Italy, Germany, France, Belgium, Netherlands, while around 24,000 tons were exported to other European countries such as Switzerland, Russia, Ukraine, Norway, and Serbia. Overseas countries such as USA, Australia, Brazil, South Africa Republic, and Japan got a smaller share from produced hazelnut of approximately 14,000 tons, half of which were exported to countries including Egypt, Israel, Tunisia, S. Arabia, and Syria (Cevik et al., 2009; THE, 2007).

Nuts and seeds were rich sources of several essential elements (e.g. B, Se, Cu, Zn, Fe, and Mn) in human nutrition, especially for vegetarian diets (Cabrera et al., 2002, Bond et al., 2005, Rodushkin et al., 2008). They had a growing popularity for various commercialized healthy diets (including Mediterranean) that relied on frequent use of nuts and seeds. On the other hand, reported accumulation of toxic elements $(\mathrm{Pb}, \mathrm{Cd}$, and $\mathrm{Tl})$ in the matrices of nuts and seeds might hinder their wider inclusion in human nutrition (Rodushkin et al., 2008, Vallilo et al., 1999, Madejon et al., 2003). Among nut species, hazelnut played a major role in human nutrition and health due to its special composition of fat (mainly oleic acid), protein, carbohydrate, dietary fiber, vitamins (vitamin E), minerals, phytosterols (mainly â-sitosterol), and antioxidant phenolics (Cevik et al., 2009; Savage \& McNeil, 1998; Ackurt et al., 1999; Maguire et al., 2004; Alasalvar et al., 2006; Seyhan et al., 2007). Besides frequent inclusion in healthy diets, hazelnuts were also used in the confectionary, and food oil market. Their great potential for use in the renewable energy market should also be noted as a study conducted by Xu et al. (2007) demonstrated that $1000 \mathrm{~kg}$ of oil could be produced from one hectare of hazelnut shrubs whereas soybean 
yield was only $500 \mathrm{~kg} \cdot \mathrm{ha}^{-1}$.

In this study, the concentration levels of 8 elements including 3 heavy metals $(\mathrm{Cu}, \mathrm{Pb}$, and $\mathrm{Cd})$ in hazelnut samples obtained from western and eastern Black Sea regions were determined and the relation among them was investigated. The aim of this study was to investigate the toxic metal pollution through analyzing hazelnut samples for significantly high heavy metal concentrations.

\section{Method}

Hazelnut samples were obtained from a hazelnut processing factory in Giresun-Turkey, which received hazelnuts from four major producer provinces, namely Bolu, Ordu, Giresun, and Trabzon. Hazelnuts, which were produced at these different regions of Turkey, were processed separately in the factory. A map indicating the origins of hazelnuts could be seen in Figure 1. Collected hazelnut samples were labeled in accordance with their origins as (F1), (F2), (F3), (F4), (F5), (F6), (F7), and (F8) representing Bolu, Akcakoca, Ordu-Ulubey, Ordu-Unye, Ordu, Giresun-Bulancak, Giresun, and Trabzon-Akcaabat, respectively.

Hazelnut samples were retrieved following the shelling and separation processes. Collected hazelnut samples were stored in polyethylene bags until analysis. Drying was conducted at $50{ }^{\circ} \mathrm{C}$ during 24 hours, which was followed by fine grinding. Approximately $1 \mathrm{~g}$ of raw sample was weighed into a Teflon digestion vessel, followed by addition of $10 \mathrm{ml}$ ultra pure nitric acid and $50 \mu \mathrm{l}$ hydrofluoric acid. Teflon containers were capped and then placed in a microwave oven (Berghof MWS-2 microwave-system). The digestion cycle was comprised of a 20-min ramp-time from room temperature to $170{ }^{\circ} \mathrm{C}$ (measured by infrared sensors), followed by a 30-min hold time at this temperature. After cooling the vessels to below $40{ }^{\circ} \mathrm{C}$, sample digests were transferred to acid-washed $50 \mathrm{ml}$ polystyrene test tubes. Samples were transferred to HDPE volumetric flasks and then flasks were filled with ultra pure water until $50 \mathrm{ml}$. Metal analyses of the prepared samples were conducted by using an ICP-OES (Perkin Elmer Optima 7000 DV) that was coupled with an autosampler (Perkin Elmer S10 Autosampler).

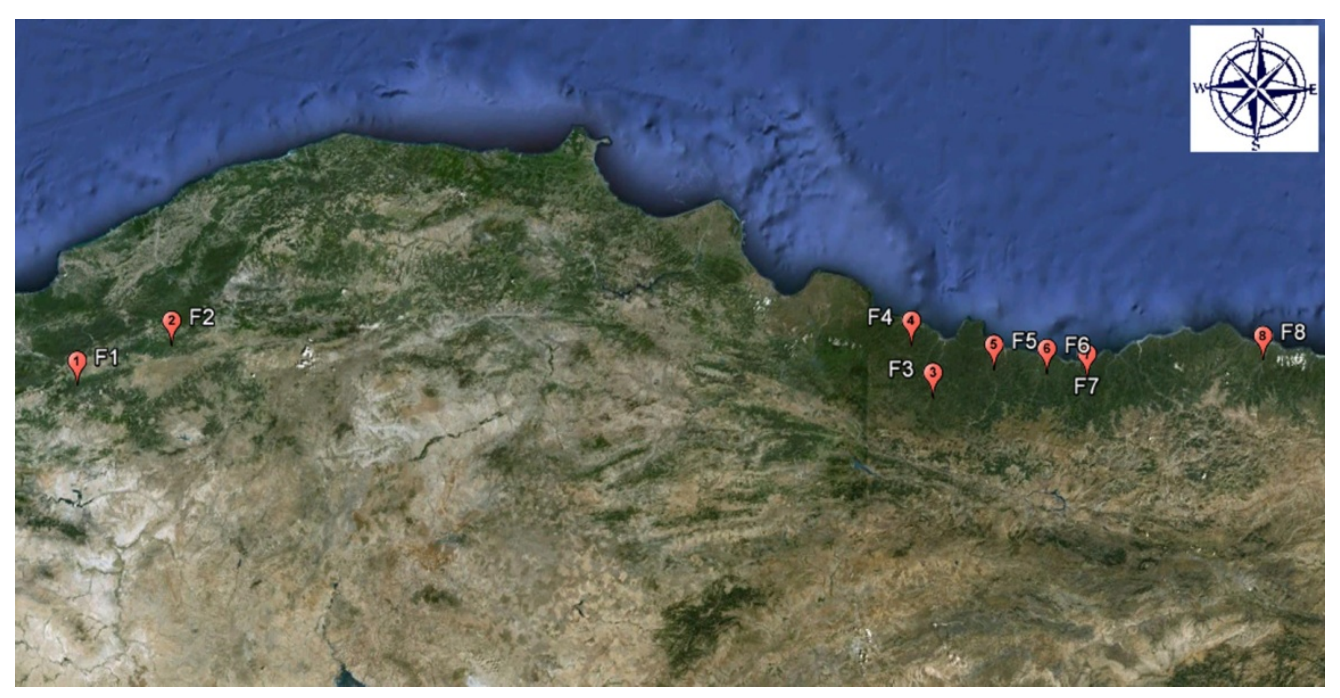

Figure 1. Location of hazelnut producing provinces of Turkey

\subsection{Estimated Daily Intake (EDI) of Heavy Metals}

The estimated daily intake (EDI) of heavy metals $(\mathrm{Cu}$ and $\mathrm{Pb})$ depended on both the metal concentration level and the amount of consumption of hazelnuts. The EDI of metals for adults was determined using the following equation (Zhuang et al., 2009).

$$
E D I=\left(C_{\text {metal }} x W\right) / B_{w}
$$

where $C_{\text {metal }}$ was the concentration of heavy metals in hazelnut; $W$ represented the daily average consumption of hazelnut; $B_{w}$ was the body weight. Calculations were made assuming body weight of $70 \mathrm{~kg}$ for adults and a $20 \mathrm{~g}$ average daily consumption (Cevik et al., 2009). 


\section{Results}

Concentrations of $\mathrm{Na}, \mathrm{Mg}, \mathrm{Ca}, \mathrm{K}, \mathrm{Fe}$, and heavy metals $\mathrm{Cu}, \mathrm{Pb}$, and $\mathrm{Cd}$ in hazelnut samples were analyzed in this study. $\mathrm{Cd}$ and $\mathrm{Pb}$ were not detected in any of the samples. In other words, $\mathrm{Cd}$ and $\mathrm{Pb}$ concentrations were below the detection limits of the ICP-OES. Main sources of $\mathrm{Pb}$ were listed as the combustion of leaded fuel, waste incineration and industrial sources. Therefore lead pollution was also correlated with urbanization and density of population (Cevik et al., 2009). The reason for not detecting $\mathrm{Pb}$ in hazelnut samples could be the low urbanization rate and related low traffic density in the regions, where the samples were collected. A summary of the mean concentration of the elements in this study and the reported values in the literature for comparative purposes are shown in Table 1.

Table 1. Element concentrations in hazelnut samples

\begin{tabular}{ccccc}
\hline Elements & $\begin{array}{c}\text { This study } \\
\text { mean, }\left(\mathrm{mg} \mathrm{kg}^{-1}\right)\end{array}$ & $\begin{array}{c}\text { Alasalvar et al. (2003) } \\
\text { mean, }\left(\mathrm{mg} \mathrm{kg}^{-1}\right)\end{array}$ & $\begin{array}{c}\text { Alasalvar et al. (2009) } \\
\text { mean, }\left(\mathrm{m} \mathrm{kg} \mathrm{k}^{-1}\right)\end{array}$ & $\begin{array}{c}\text { Rodushkin et al. (2008) } \\
\text { Mean }\end{array}$ \\
\hline $\mathrm{Na}$ & 14.1 & 31.3 & 17.7 & $2.6\left(\mathrm{mg} \mathrm{kg}^{-1}\right)$ \\
$\mathrm{Mg}$ & 585.1 & 1765 & 1038.6 & $0.2(\%)$ \\
$\mathrm{Ca}$ & 629.2 & 1934 & 2082 & $0.14(\%)$ \\
$\mathrm{K}$ & 2348.4 & 7610 & 6782 & $0.90(\%)$ \\
$\mathrm{Fe}$ & 27.8 & 49.7 & 39.5 & $42\left(\mathrm{mg} \mathrm{kg}^{-1}\right)$ \\
$\mathrm{Cu}$ & 2.4 & 16 & 13.8 & $18\left(\mathrm{mg} \mathrm{kg}^{-1}\right)$ \\
\hline
\end{tabular}

The highest $\mathrm{Na}$ concentration $\left(24.7 \mathrm{mg} \cdot \mathrm{kg}^{-1}\right)$ was detected in $\mathrm{F} 8$ samples, and the lowest Na concentration (6.44 $\mathrm{mg} \cdot \mathrm{kg}^{-1}$ ) was found in F5 samples (Figure 2). In the study of Rodushkin et al. (2008), the mean concentration of $\mathrm{Na}$ in hazelnut was reported to be $2.6 \mathrm{mg} \cdot \mathrm{kg}^{-1}$. Sodium (Na) levels detected in the present study were quite higher than the findings of Rodushkin et al. (2008), while they were lower than the values $\left(31.3 \mathrm{mg} \cdot \mathrm{kg}^{-1}\right)$ reported by Alasalvar et al. (2003) (Table 1). However a more recent study by Alasalvar et al. (2009) reported similar results for $\mathrm{Na}$. The highest $\mathrm{Fe}$ concentration $\left(71.68 \mathrm{mg} \cdot \mathrm{kg}^{-1}\right.$ ) was detected in $\mathrm{F} 4$ sample, and the lowest concentration (8.46) was detected in F7 sample (Figure 2). The mean Fe concentration (27.76 $\mathrm{mg} \cdot \mathrm{kg}^{-1}$ ) determined in the present study was lower than the values measured by Rodushkin et al. (2008) and Alasalvar et al. (2003; 2009) (Table 1).

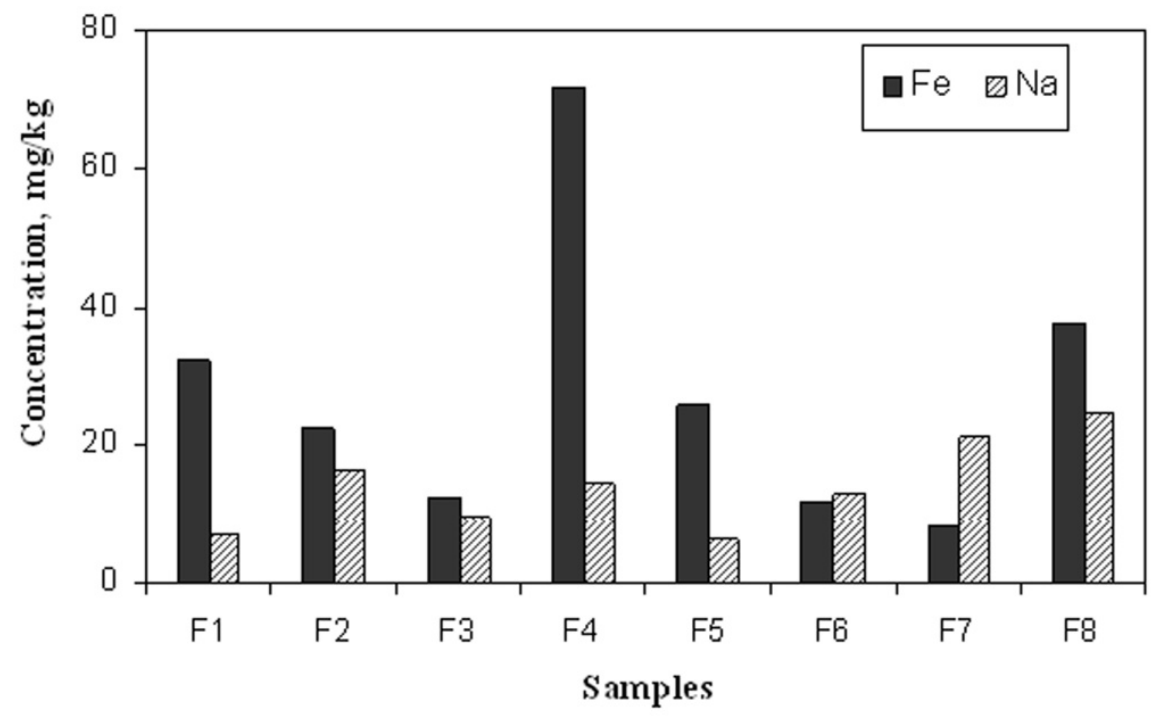

Figure 2. $\mathrm{Na}$ and $\mathrm{Fe}$ concentration distribution of hazelnut samples 
The highest Mg concentration (1052.4 $\mathrm{mg} \cdot \mathrm{kg}^{-1}$ ) was detected in F1 samples, while the lowest Mg concentration value (141.72 $\mathrm{mg} \cdot \mathrm{kg}^{-1}$ ) was found in F5 samples (Figure 3). The Mg concentrations determined in the present study were lower (approximately by $0.20 \%$ ) than the findings of Rodushkin et al. (2008). Alasalvar et al. (2003; 2009) measured the mean $\mathrm{Mg}$ concentration as $1765 \mathrm{mg} \cdot \mathrm{kg}^{-1}$ and $1038.6 \mathrm{mg} \cdot \mathrm{kg}^{-1}$ in 2003 and 2009 studies respectively (Table 1). The latter value for $\mathrm{Mg}$ was significantly lower than the former one, however it was still quite higher than the mean results retrieved in this study. The highest Ca concentration $\left(1142.8 \mathrm{mg} \cdot \mathrm{kg}^{-1}\right)$ was detected in F1 samples, while the lowest Ca concentration $\left(140.96 \mathrm{mg} \cdot \mathrm{kg}^{-1}\right.$ ) was detected in $\mathrm{F} 5$ samples (Figure 3). Measured $\mathrm{Ca}$ concentrations were lower (approximately by $0.14 \%$ ) than the findings of Rodushkin et al. (2008) and Alasalvar et al. (2003; 2009) (Table 1).

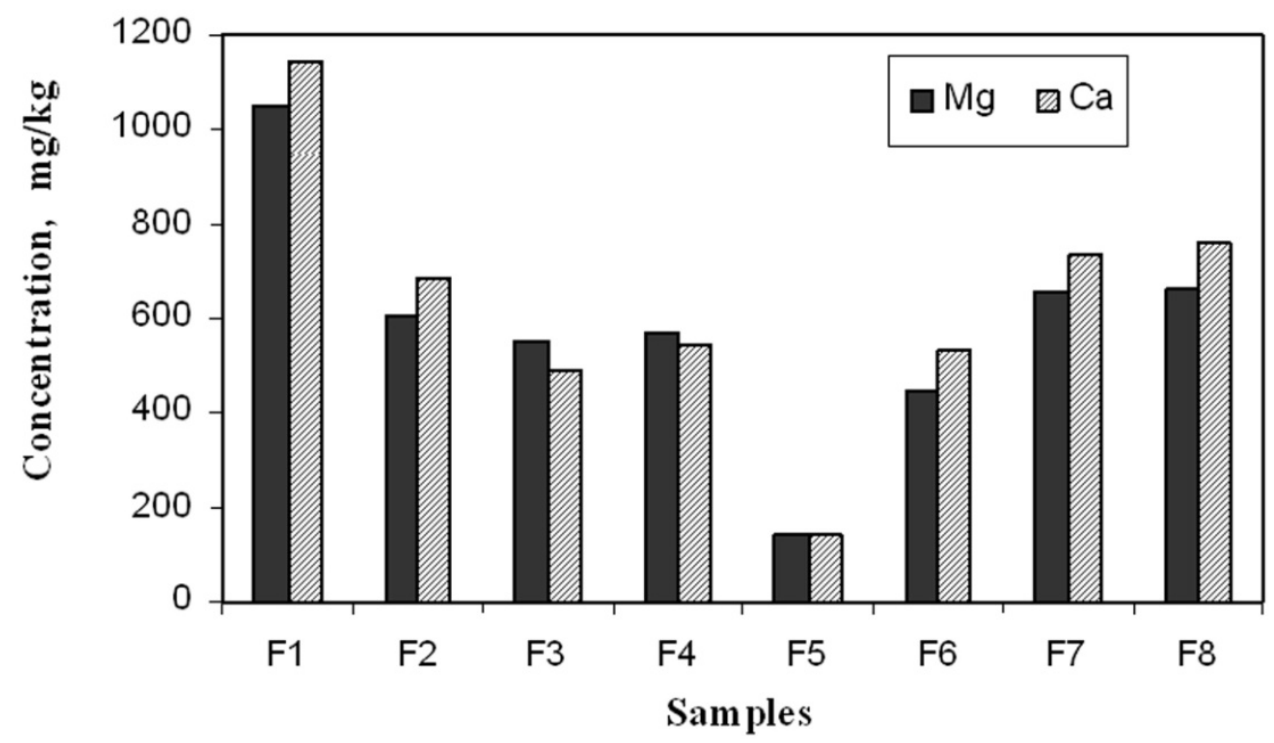

Figure 3. Mg and Ca concentration distributions for hazelnut samples

Potassium (K) was detected to be the most abundant element in hazelnut samples with an average concentration of $2348 \mathrm{mg} \cdot \mathrm{kg}^{-1}$, and with a maximum of $4248 \mathrm{mg} \cdot \mathrm{kg}^{-1}$ for Bolu (F1) sample. The highest K concentration (4248 $\left.\mathrm{mg} \cdot \mathrm{kg}^{-1}\right)$ was measured in $\mathrm{F} 1$ samples, while the lowest $\mathrm{K}$ concentration $\left(722.8 \mathrm{mg} \cdot \mathrm{kg}^{-1}\right)$ was found in $\mathrm{F} 5$ samples (Figure 4a). The mean $\mathrm{K}$ content in hazelnut samples was measured as $0.90 \%$ by Rodushkin et al. (2008). K concentrations in the present study were lower than the findings of Rodushkin et al. (2008) and Alasalvar et al. $(2003 ; 2009)$ (Table 1$)$. On the opposite side of the spectrum copper $(\mathrm{Cu})$ was measured with the lowest average concentration of $2.38 \mathrm{mg} \cdot \mathrm{kg}^{-1}$. The highest $\mathrm{Cu}$ concentration $\left(11.4 \mathrm{mg} \cdot \mathrm{kg}^{-1}\right)$ was detected in $\mathrm{F} 5$ samples, and the lowest $\mathrm{Cu}$ concentration (below the detection limit) was measured in F2 samples (Figure 4b). $\mathrm{Cu}$ values measured in the present study were lower than the values reported by other studies given in Table 1 .

Correlation analyses were carried out for the measured concentrations (Table 2). In general, positive correlation was determined between the elements investigated in the present study, except for $\mathrm{Cu}$, which was negatively correlated with $\mathrm{Fe}$ and $\mathrm{K}$. 


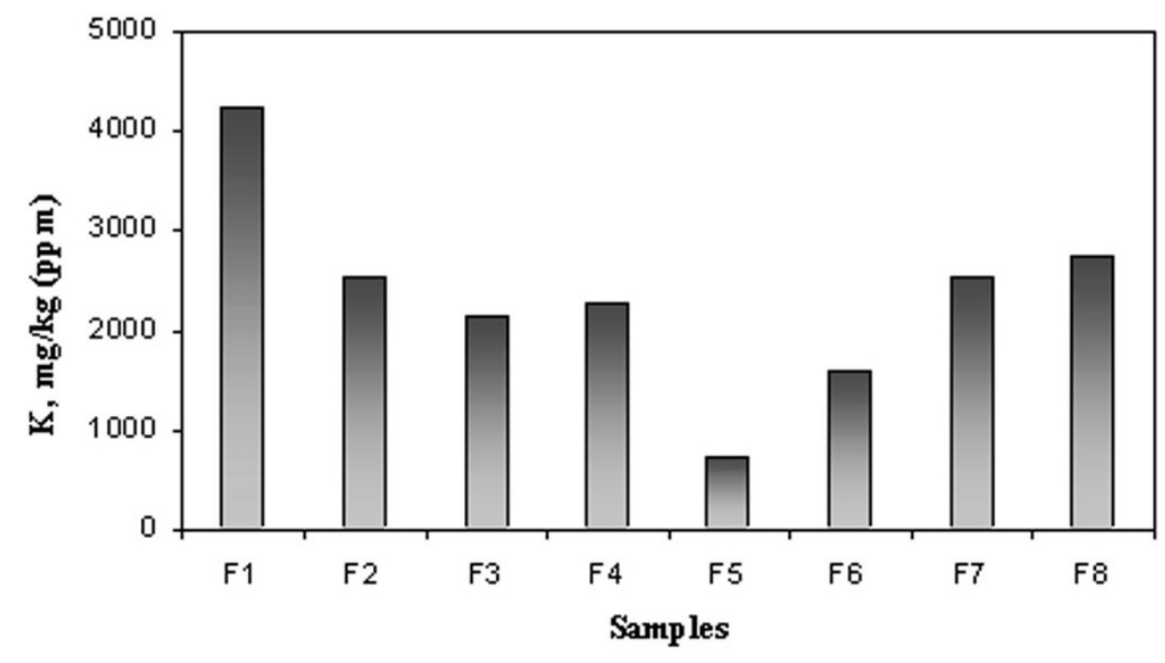

a

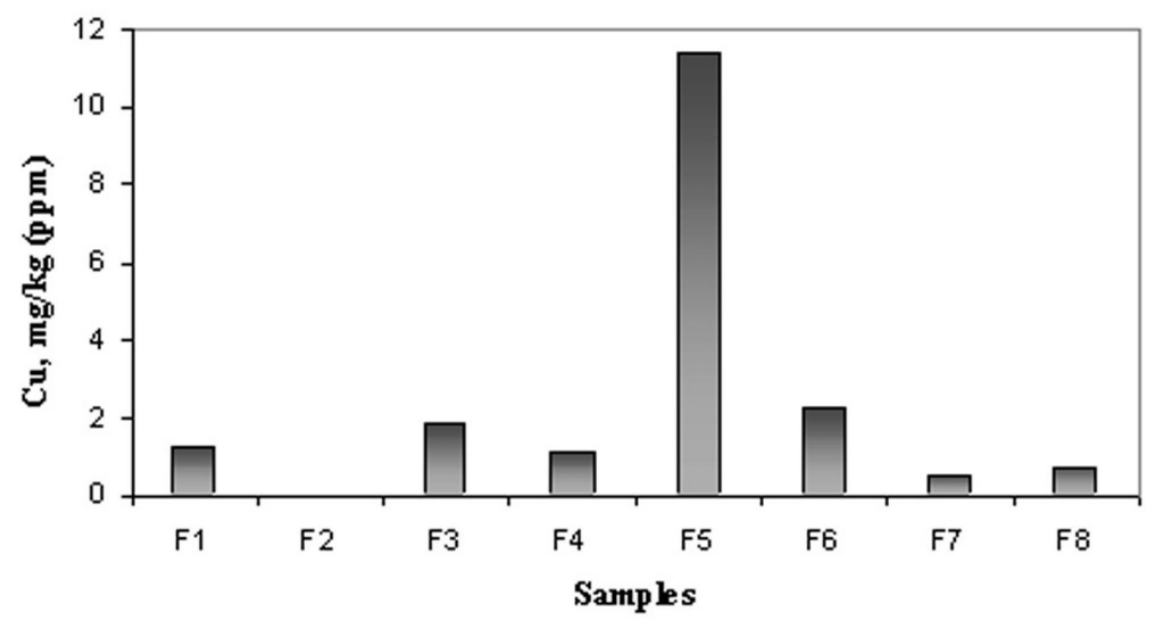

b

Figure 4. Concentration distributions for hazelnut samples: a) Potassium concentrations, b) Copper concentrations

Table 2. Correlation coefficients matrix

\begin{tabular}{ccccccc}
\hline & $\mathrm{Na}$ & $\mathrm{Mg}$ & $\mathrm{Ca}$ & $\mathrm{K}$ & $\mathrm{Fe}$ & $\mathrm{Cu}$ \\
\hline $\mathrm{Na}$ & 1 & 0.0260 & 0.0648 & 0.0253 & 0.0022 & 0.3202 \\
$\mathrm{Mg}$ & 0.0268 & 1 & 0.958 & 0.9866 & 0.5288 & 0.5288 \\
$\mathrm{Ca}$ & 0.0648 & 0.9580 & 1 & 0.9492 & 0.0031 & 0.5194 \\
$\mathrm{~K}$ & 0.0253 & 0.9866 & 0.9492 & 1 & 0.0277 & -0.4702 \\
$\mathrm{Fe}$ & 0.0022 & 0.5288 & 0.0031 & 0.0277 & 1 & -0.0045 \\
$\mathrm{Cu}$ & 0.3202 & 0.5288 & 0.5194 & -0.4702 & -0.0045 & 1 \\
\hline
\end{tabular}

Reported estimated daily intakes (EDI) of heavy metals were $0.5 \mathrm{mg} \cdot \mathrm{kg}^{-1}$ PMTDI (Provisional Maximum Tolerable Daily Intake) for $\mathrm{Cu}, 0.025 \mathrm{mg} \cdot \mathrm{kg}^{-1}$ PTWI (Provisional Tolerable Weekly Intake) for $\mathrm{Pb}$ and 0.007 $\mathrm{mg} \cdot \mathrm{kg}^{-1}$ PTWI for Cd (WHO, 1982; 2000; 2006). According to Equation1, calculated EDI value for Cu was $6.8 \mathrm{x}$ $10^{-4} \mathrm{mg} \cdot \mathrm{kg}^{-1}$. It was shown that the calculated EDI values for daily average consumption $(20 \mathrm{~g})$ were lower than the recommended values for $\mathrm{Cu}$. On the other hand, $\mathrm{Cd}$ and $\mathrm{Pb}$ were not detected in any of the samples. For this reason there was no need to calculate EDI values for these heavy metals. 


\section{Discussion}

According to the findings of the present study, heavy metal concentrations in the hazelnut samples collected from three different production regions were in accordance with a healthy diet from the perspective of public health. Also, anthropogenic pollution could be claimed to be minimal at these regions due to the absence of industrial facilities and low transportation rate.

In Table 1 there were some discrepancies between the results reported in this study and in the literature. That may be due to changing mineral composition of the hazelnuts, which were affected by factors such as geographic location, harvest time, climate, soil structure and fertilizers (Bonvehi \& Coll, 1993; Ackurt et al., 1999). The hazelnut samples investigated in the study were found to be rich in $\mathrm{K}, \mathrm{Ca}$ and $\mathrm{Mg}$. In addition, hazelnut samples were observed as a good source of iron with an average of $27.76 \mathrm{mg} \cdot \mathrm{kg}^{-1}$.

Low concentrations of heavy metals in hazelnut samples investigated in the study $\mathrm{Pb}$ and $\mathrm{Cd}$ were below the detection limits) could be attributed to the low industrialization and traffic density at the regions, where the samples were collected.

The most important result of this research was that examined Turkish hazelnuts were safe from the human health risk point of view. Also their contents of $\mathrm{Cu}, \mathrm{Pb}$, and $\mathrm{Cd}$ were low enough to guarantee that human daily intake remained below tolerable levels of PMTDI and PTWI.

\section{References}

Ackurt, F., Ozdemir, M., Biringen, G., \& Loker, M. (1999). Effects of geographical origin and variety on vitamin and mineral composition of hazelnut (Corylus avellana L.) varieties cultivated in Turkey. Food Chemistry, 65, 309-313. http://dx.doi.org/10.1016/S0308-8146(98)00201-5

Alasalvar, C., Amaral, J. S., \& Shahidi, F. (2006). Functional lipid characteristics of Turkish tombul hazelnut (Corylus avellana L.). Journal of Agriculture and Food Chemistry, 54, 10177-10183. http://dx.doi.org/10.1021/jf061702w

Alasalvar, C., Amaral, J. S., Satir, G., \& Shahidi, F. (2009). Lipid characteristics and essential minerals of native Turkish hazelnut varieties (Corylus avellana L.). Food Chemistry, 113, 919-925. http://dx.doi.org/10.1016/j.foodchem.2008.08.019

Alasalvar, C., Shahidi, F., Liyanapathirana, C. M., \& Ohshima, T. (2003). Turkish tombul hazelnut (Corylus avellana L.) compositional characteristics. Journal of Agricultural and Food Chemistry, 51, 3790-3796. http://dx.doi.org/10.1021/jf0212385

Bond, B., Fernandez, D. R., Jagt, D. J. V., Williams, M., Huang, Y. S., Ghuang, L. T., ... Glew, R. H. (2005). Fatty acid, amino acid and trace mineral analysis of three complimentary foods from Jos, Nigeria. Journal of Food Composition and Analysis, 18, 675-690. http://dx.doi.org/10.1016/j.jfca.2004.06.006

Bonvehi, J. S., \& Coll, F. V. (1993). Oil content, stability and fatty acid composition of the main varieties of Catalonian hazelnuts (Corylus aVellana L.). Food Chemistry, 48, 237-241. http://dx.doi.org/10.1016/0308-8146(93)90133-Z

BSEA. (2011, February 6). Black Sea Exporters' Association. Retrieved from http://www.kib.org.tr

Cabrera, C., Lloris, F., Gimenez, R., Olalla, M., \& Lopez, C. (2002). Mineral content in legumes and nuts: contribution to the Spanish dietary intake. Science of Total Environment, 308, 1-14. http://dx.doi.org/10.1016/S0048-9697(02)00611-3

Cevik, U., Celik, N., Celik, A., Damla, N., \& Coskuncelebi, K. (2009). Radioactivity and heavy metal levels in hazelnut growing in the Eastern Black Sea Region of Turkey. Food Chemistry and Toxicology, 47, 2351-2355. http://dx.doi.org/10.1016/j.fct.2009.06.029

FTG. (2011). Findlk Tanitim Grubu. Retrieved from http://www.ftg.org.tr/devam tur/turkiye.htm

Madejon, P., Murillo, J. M., Maranon, T., Cabrera, R., \& Soriano, M. A. (2003). Trace element and nutrient accumulation in sunflower plants two years after the Aznalcollar mine spill. Science of Total Environment, 307, 239-257. http://dx.doi.org/10.1016/S0048-9697(02)00609-5

Maguire, L. S., O’Sullivan, S. M., Galvin, K., O'Connor, T. P., \& O’Brien, N. M. (2004). Fatty acid profile, tocopherol, squalene and phytosterol content of walnuts, almonds, peanuts, hazelnuts and the macadamia nut. International Journal of Food Science and Nutrition, 3, 171-178. http://dx.doi.org/10.1080/09637480410001725175 
Rodushkin, I., Engström, E., Sörlin, D., \& Baxter, D. (2008). Levels of inorganic constituents in raw nuts and seeds on the Swedish market. Science of Total Environment, 392(2-3), 290-304. http://dx.doi.org/10.1016/j.scitotenv.2007.11.024

Savage, G. P., \& McNeil, D. L. (1998). Chemical composition of hazelnuts (Corylus avellana L.) grown in New Zeland. International Journal of Food Science and Technology, 49, 199-203.

Seyhan, F., Ozay, G., Saklar, S., Ertas, E., Satır, G., \& Alasalvar, C. (2007). Chemical changes of three native Turkish hazelnut varieties (Corylus avellana L.) during fruit development. Food Chemistry, 105, 590-596. http://dx.doi.org/10.1016/j.foodchem.2007.04.016

THE. ( 2007). Turkish hazelnut exporter's union: The Turkish hazelnut. Giresun, Turkey.

Vallilo, M. I., Tavares, M., Aued-Pimentel, S., Campos, N. C., \& Moita-Neto, J. M. (1999). Lecythis pisonis Camb. Nuts: oil characterization, fatty acids and minerals. Food Chemistry, 66, 197-200. http://dx.doi.org/10.1016/S0308-8146(99)00040-0

WHO (World Health Organisation). (1982). Evaluation of Certain Food Contaminants. Twenty-Six of the Joint FAO/WHO Expert Committee on Food Additives, Geneva.

WHO (World Health Organisation). (2000). Evaluation of Certain Food Contaminants. Fifty-Third of the Joint FAO/WHO Expert Committee on Food Additives, Geneva.

WHO (World Health Organisation). (2006). Evaluation of Certain Food Contaminants. Sixty-fourth report of the Joint FAO/WHO Expert Committee on Food Additives, Geneva.

Xu, Y. X., Hanna, M. A., \& Josiah, S. J. (2007). Hybrid hazelnut oil characteristics and its potential oleochemical application. Indian Crop Production Journal, 26, 69-76. http://dx.doi.org/10.1016/j.indcrop.2007.01.009

Zhuang, P., McBride, M. B., Xia, H., Li, N., \& Li, Z. (2009). Health risk from heavy metals via consumption of food crops in the vicinity of Dabaoshan mine. South China. Science of Total Environment, 407, 1551-1561. http://dx.doi.org/10.1016/j.scitotenv.2008.10.061 